\title{
The Potential Role of Artificial Marsh on Coastal Protection in Long Island Sound
}

\author{
Amin Ilia ${ }^{1}$ \\ 1 University of Connecticut, Groton, CT 06340
}

\begin{abstract}
Connecticut marshes, like other marshes in the world, are vulnerable to anthropogenic and climate change effects. However, assessment of current sea level rise and average marsh accretion rates in Connecticut demonstrate sea level rise is not the main vulnerable factor for salt marshes loss. The study on the feasibility of developing an ecosystem-based on two coastlines in Connecticut, Guilford and Stratford, shows that both coastlines, like other coastlines in Connecticut, have limited wave energy, which is a positive factor for marsh growth. The available data assessment represents that sediment supply is the most important parameter to guarantee the resilience and sustainability of a newly developed salt marsh system in Connecticut. In Stratford, conditions for establishing a new ecosystem seem to be better, as the fetch length is pretty small, and there is some sediment supply for the ecosystem. In Guilford, wave energy is limited, but it is more than in Stratford case. Besides, sediment availability is low and the coastline experienced considerable erosion during hurricane Sandy and has not recovered yet.
\end{abstract}

\section{Introduction}

According to the United Nations Report, more than $40 \%$ of the world's population lives in coastal area. However, coastal areas are threatened by natural coastal hazards such as hurricanes, storm surges and tsunamis. The accelerated Sea-level Rise (SLR) and climate changes have increased the cost of coastal infrastructures. That's why the demand for a resilient and sustainable coastal protection system adapted to climate change and coastal ecology has increased in recent years.

For centuries, coastal structures such as seawalls, detach breakwaters, groins, and revetments have been constructed to protect coastal properties. Although these traditional shoreline protection methods have many advantages, their effectiveness diminishes over time, and they are not adaptable to the coastal situation (O'Donnell, 2016; Sutton et al., 2015; Temmerman et al., 2013). Furthermore, it has been shown that traditional structures cause coastal erosion downstream and some loss of available sediment for longshore transport (O'Donnell, 2016). Hence, applying an ecosystem-based coastal defense system has been increased remarkably in recent years. 
Ecosystem-based approaches offer protection against erosion and the creation or restoration of coastal habitats (O'Donnell, 2016). Nevertheless, the value of benefits and the sustainability provided by these structures has not been understood completely. While lots of questions about the resilience and benefits of these systems are not answered, few constructed ecosystem-based systems around the world, such as Scheldt estuary in Belgium and Chesapeake Bay program, have shown positive physical, environmental, and ecological effects (O'Donnell, 2016; Sutton et al., 2015; Temmerman et al., 2013).

Generally, built infrastructure is well understood and has been used in coastal protection for decades, but it has a limited lifetime, weakens with time, and is constructed to specific parameters that cannot adapt to changing sea levels or other conditions. While an ecosystem-based system is not well understood, it has been shown that the system not only provides benefits for habitant, environment, coastline but can recover and resilient after extreme conditions (Gittman et al., 2014; Sutton et al., 2015).

Salt marshes are one of the ecosystem-based systems which can be applied for protecting shorelines (Gittman et al., 2014); but still, there are a lot of uncertainties about the resilience of salt marshes in different climate and conditions. In this study, different salt marsh characteristics and the current condition of natural salt marshes in Connecticut are reviewed. Finally, two points of Connecticut's coastline with erosion problem are studied for investigating the possibility of using marsh, as an ecosystem-based system, to stabilize the coastline.

\section{Method}

The response of marshes to some coastal phenomena and the conditions for resiliency has been reviewed. In addition, an investigation was performed on available data for Connecticut marshes to understand the current condition, important stressors, and resiliency of the marshes. In this section, feasible studies will be performed for establishing an ecosystem-based coastal defense system at two sites on Connecticut coastline Chittenden Park in Guilford and Short Beach in Stratford.

In order to have a successful and sustainable salt marsh for erosion control, a low wave energy area must be provided for marsh growth. The majority of sea-waves energy attenuate at few 10 meters of marsh edge. Therefore it's not usually required to develop a wide wetland for erosion control purposes. Moreover, sediment supply must be enough to guarantee an accretion rate equal or larger than SLR rate. Finally, it is crucial to create a gentle slope at the upland area to ease marsh migration.

Before analyzing the coastlines, wind and wave conditions in Long Island Sound will be reviewed. The central long island sound buoy with coordinates 41 $8^{\prime} 15^{\prime \prime} \mathrm{N} 72^{\circ} 39^{\prime} 18^{\prime \prime} \mathrm{W}$, owned and maintained by UCONN, were used to analyze wind and wave conditions in Long Island Sound. 
The majority of winds blow from the west, while the average wind speed of northern winds is more than the southern ones (Figure 1). Given that the long west-east fetch and short north-south fetch in LIS (Figure 2), the dominant wave direction in the deep part of LIS must be from west and northwest. Therefore, LIS's southern coastline (New York coasts) should experience more energy than the northern coastlines (Connecticut).

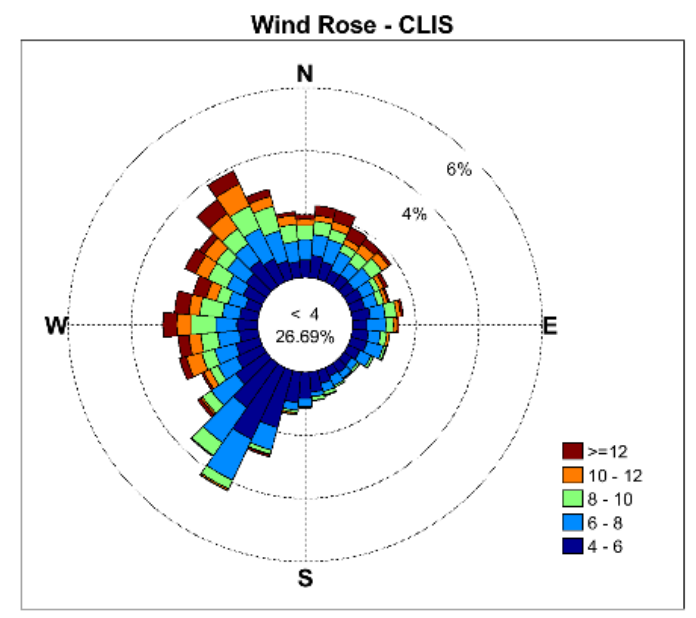

Figure 1: Windrose for central Long Island Sound. The wind-rose indicates where the winds come from. The Prevailing wind directions in LIS are from northwest, west, and southwest with higher intensity (average wind speed for northwest winds)

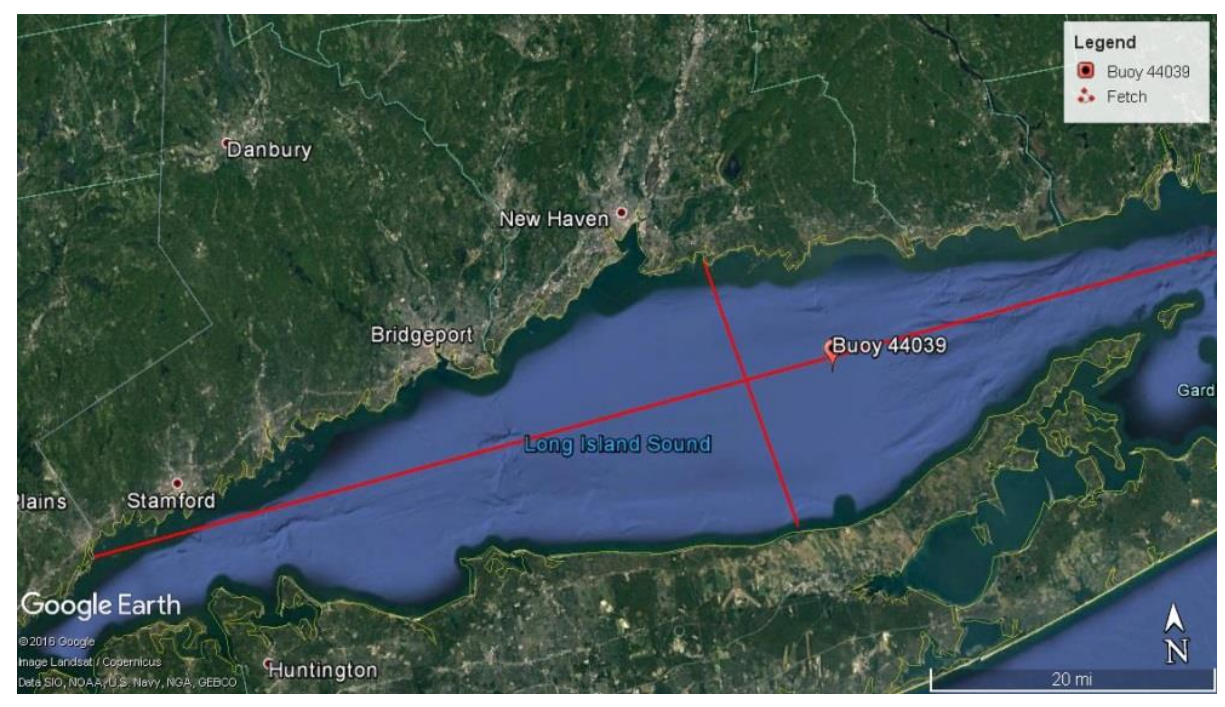

Figure 2: Fetches distance and Buoy location in Long Island sounds, longest fetch has a west-east alignment with $140 \mathrm{~km}$. 


\section{Results}

\subsection{Chittenden Park, Guilford, CT}

Chittenden Park, located in east Connecticut, is surrounded by West River at west and a headland at the east side. As headlands protect the coastline in both west and east sides, the fetch length is limited in the area; therefore, the dominant waves from the west would not affect the coastline directly and just some diffracted southwest waves can reach the coastline, Figure 3. . Maximum fetch length is about $35 \mathrm{~km}$ and although wave energy is limited in the area, marshes still need protection. Marshes cannot tolerate high energy wave and a calm condition must be provided for growing marsh which would be established for erosion control purposes.

Using Google Earth's historical satellite images, the current coastline condition was investigated. The oldest available satellite image of Google Erath (04/22/1990) and the newest one (04/20/2016) were studied to figure out coastline evolution in 16 years, Figure 4 . The results indicate high erosion conditions in the area. More than $8000 \mathrm{~m}^{2}$ of the coastline has vanished in 16 years. The coastline includes a combination of consecutive non-vegetated and vegetated coastline. The vegetated part seems to survive the part of an old coastal salt marsh which is eroding gradually. The majority of erosion took place in non-vegetated parts of the coastline and the vegetated had not been eroded as much as the non-vegetated coast. According to the two digital areal images, before (3/29/2012) and after (9/19/2010), the majority of erosion in the vegetated part has happened during hurricane Sandy, Figure 5. This represents that the vegetated area can be used for erosion protection in usual conditions, but they should be protected for extreme storms. It can be seen from the images that the gradual erosion of remained salt marsh has not stopped after Sandy; therefore, they must be protected before they completely disappeared.

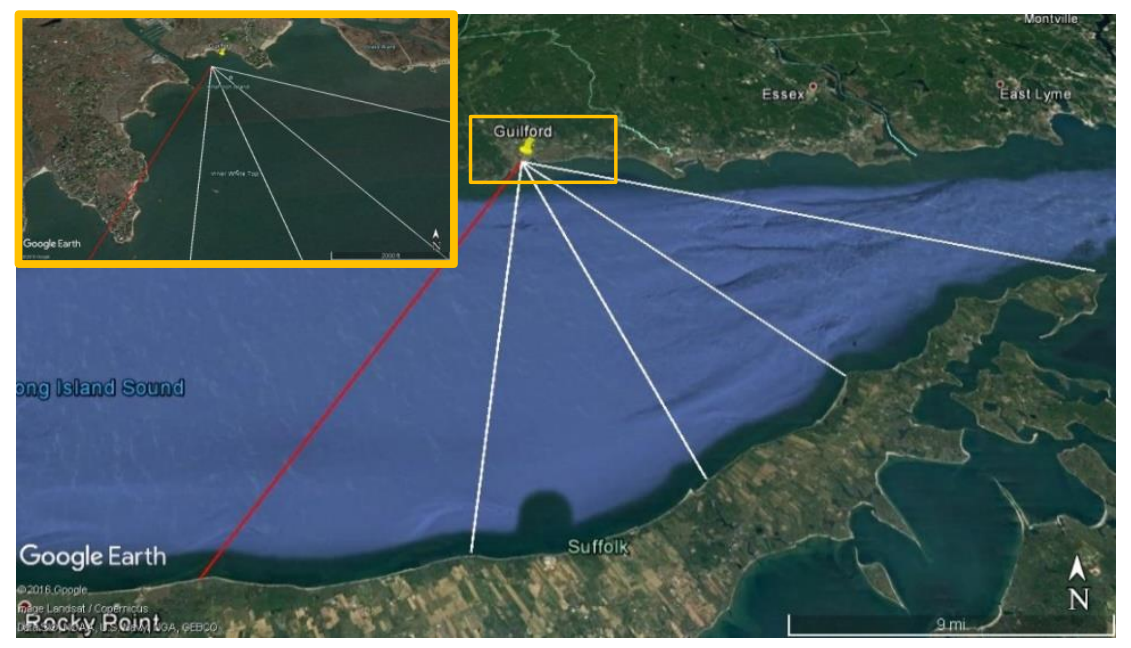

Figure 3: Possible wave fetch for Chittenden Park, Guilford, the area is protected by eastern headlands; fetch length varies from $25 \mathrm{~km}$ to $35 \mathrm{~km}$, the red line represents the fetch with the most intensive wind. However, the diffracted waves from this direct impact on Chittenden park coastline. 

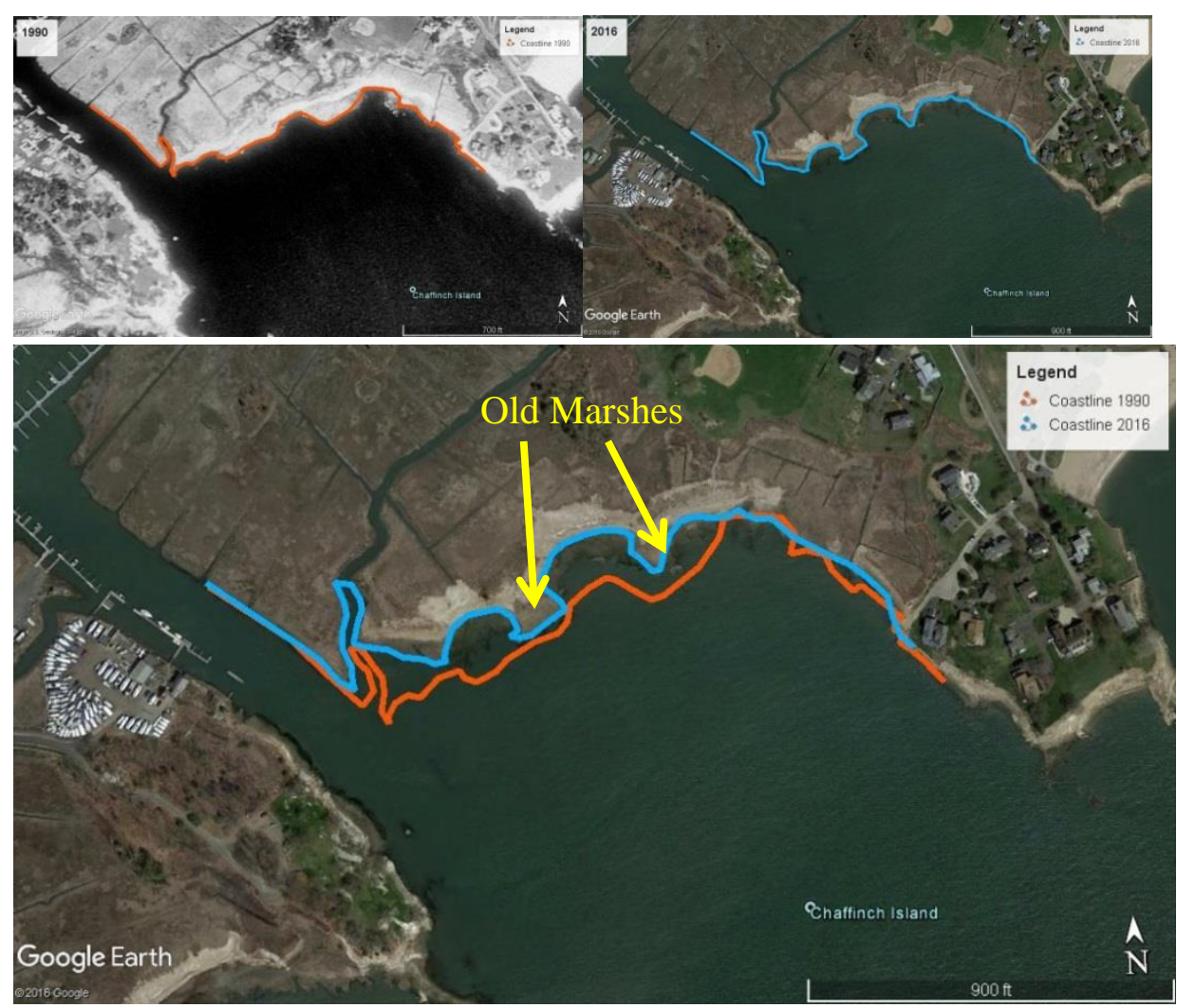

Figure 4: Comparison of coastal variations between 04/22/1990 and 04/20/2016 (16 years) in Chittenden Park, Guilford, top left: 1990 image, top right: 2016 image, bottom: the Comparison of two coastlines. More than $8000 \mathrm{~m}^{2}$ $\left(88000 \mathrm{ft}^{2}\right)$ of the coastline drawn and eroded in just 16 years.

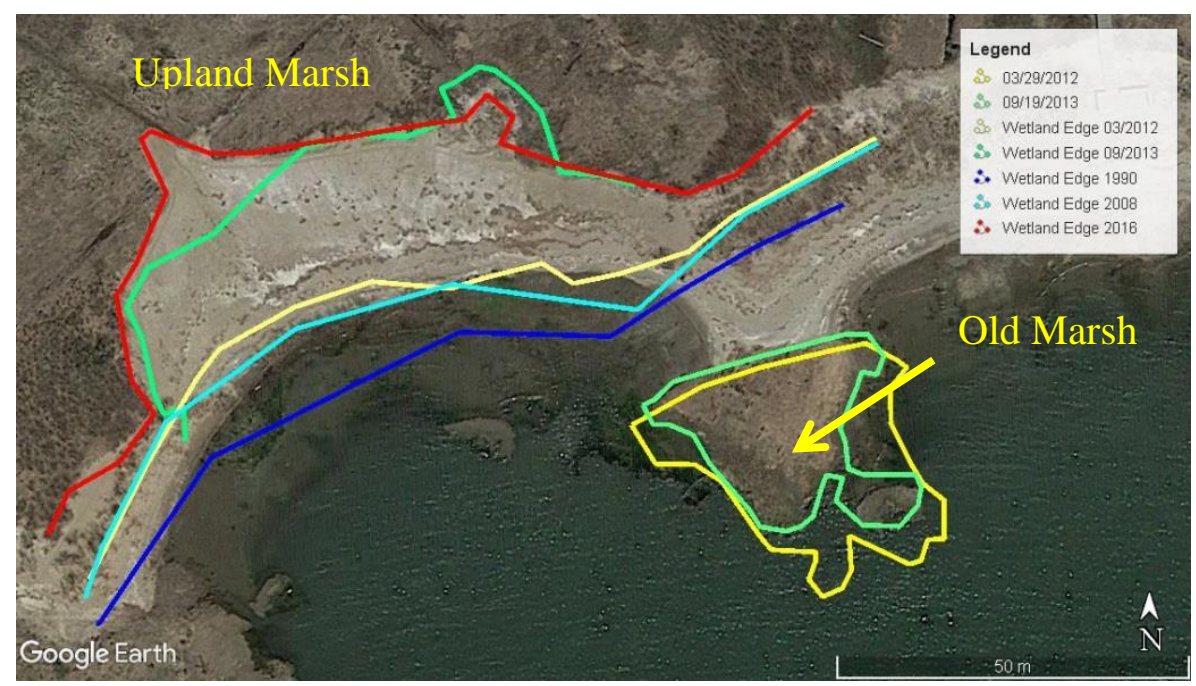

Figure 5: Comparison of digital images, a: remained coastal salt marsh before (3/29/2012) and after (9/19/2010) hurricane Sandy, b: upland marsh erosion, 1990, 2008, before Sandy (3/29/2012), after Sandy (04/20/2016), 2016. Hurricane Sandy happened on 10/29/2012; Comparison shows that the majority of erosion in vegetated areas took place during Hurricane Sandy. 


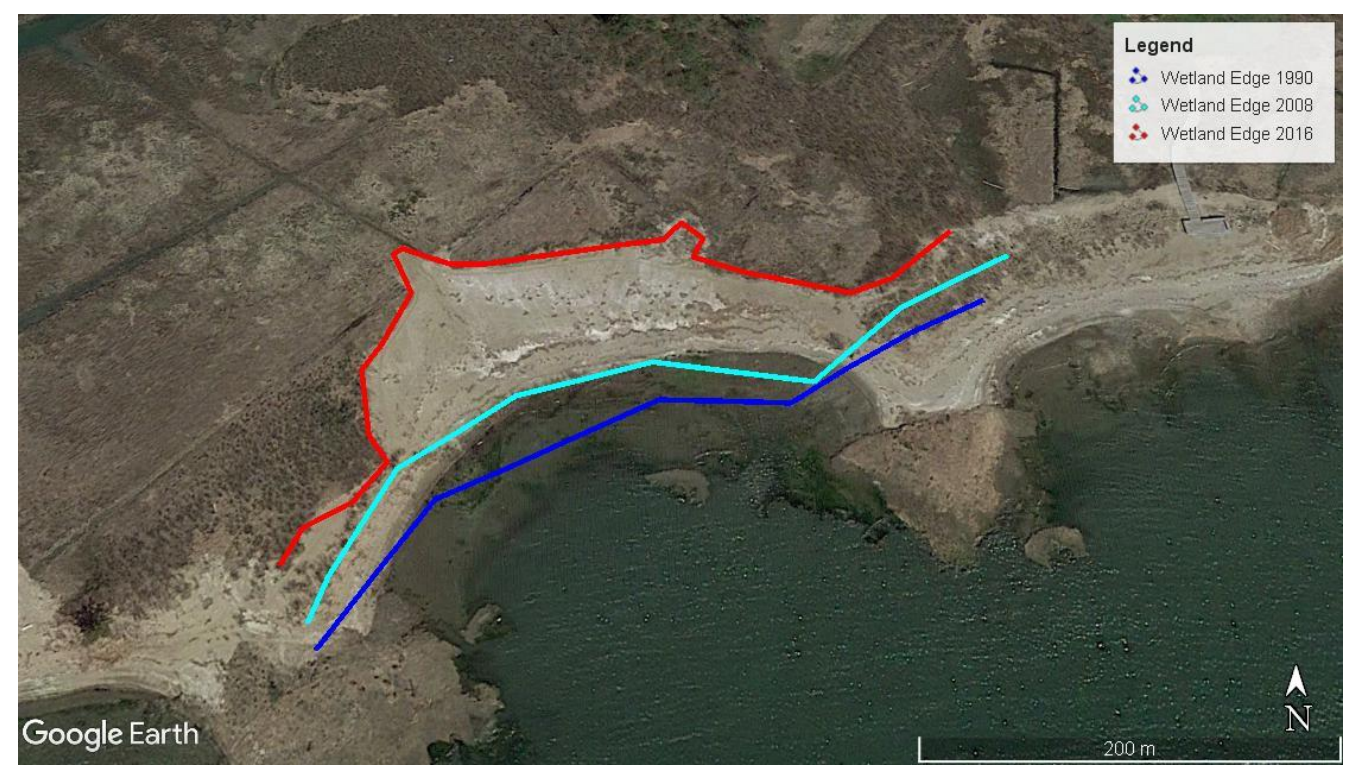

Figure 6: Marsh edge loss based on digital image of 1990, 2008 and 2016, Marsh edge loss between 2008 and 2016 (8 years) is much larger than period between 1990 and 2008 (16 years)

The presence of rocky headlands in the adjacent area represents the lack of sediment sources and it seems that the West River is the only sediment source entering the system. However, the river has a small drainage area and it might not be able to inject enough sediment into the coastline to guarantee coastline resiliency. To design an ecosystem-based system for the coastline, a comprehensive study should be done on the amount of sediment annually deposes from the river into the coastline. It must be calculated how much of those sediments can be trapped by the ecosystem-based protection system.

In order to imply an artificial marsh on the coastline, it is crucial to attenuate the wave energy, which can be done by setting a group of reef balls or small detach breakwater in front of the coastline. These reef balls are sufficient to attenuate wave energy and they would be a suitable place for marine habitat to live, (O'Donnell 2015), Figure 7. Furthermore, some marshes must be set up on the coastline between the reef balls and current beach for deposing sediments and stabilizing shoreline, Figure 8. Again, the availability of sediment supplies is essential for the resiliency of salt marsh and the designed system must be able to accumulate sediments entering from West River. 


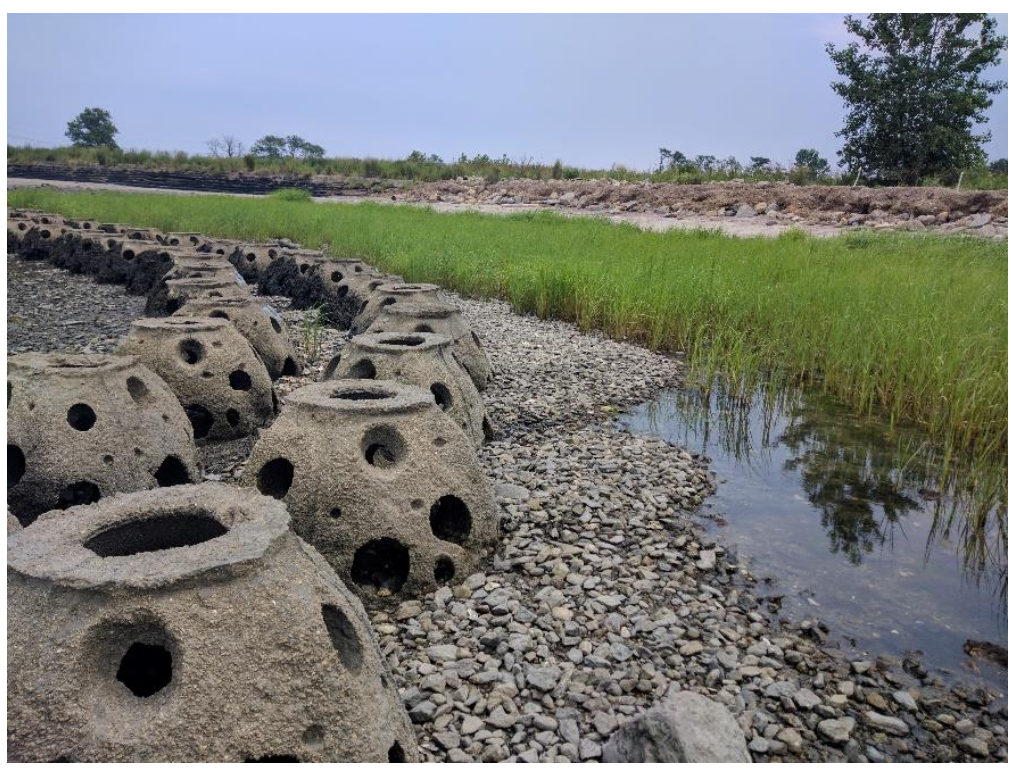

Figure 7: Reef balls can be used for attenuating wave instead of breakwater

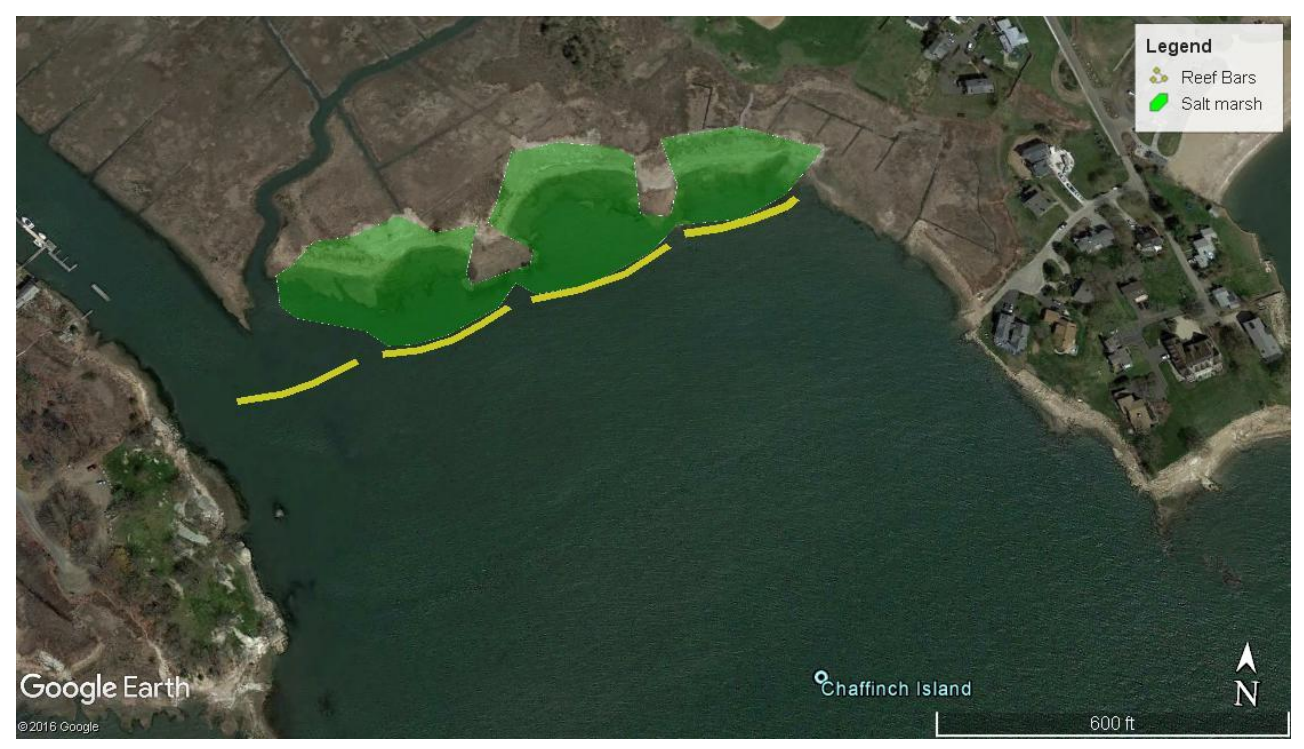

Figure 8: Proposed resilience plan for protecting the coastline, Yellow lines: reef balls, Green polygon: salt marsh. This is just a fundamental plan. To have a sustainable and resilience protection system and ensure about accretion rates of salt marsh, a comprehensive study should be done on sediment supply from West River and circulation in the coastline. The system should be able to accumulate sediment supplies from West River.

\subsection{Short Beach, Stratford, CT}

Short beach, located in Stratford at southern of Housatonic River mouth, is surrounded by a sandy beach at the North and a mixture of sand and gravel at the south. There is a rocky headland that has been protected by a revetment. Due to a detached breakwater in front of the coastline, the fetch 
is strongly limited and the maximum fetch length is about $2 \mathrm{~km}$ from the North, Figure 9 . Therefore, wave energy is strongly limited and tidal and river currents are the primary source of energy in the coastline. The existence of a sandy beach at North demonstrates that there must be enough sediment sources from north and Housatonic River. In addition, the detached breakwater has been built for protecting navigation channel from waves, though it produced a calm condition for growing salt marsh and developing sandy beach on the coastline.

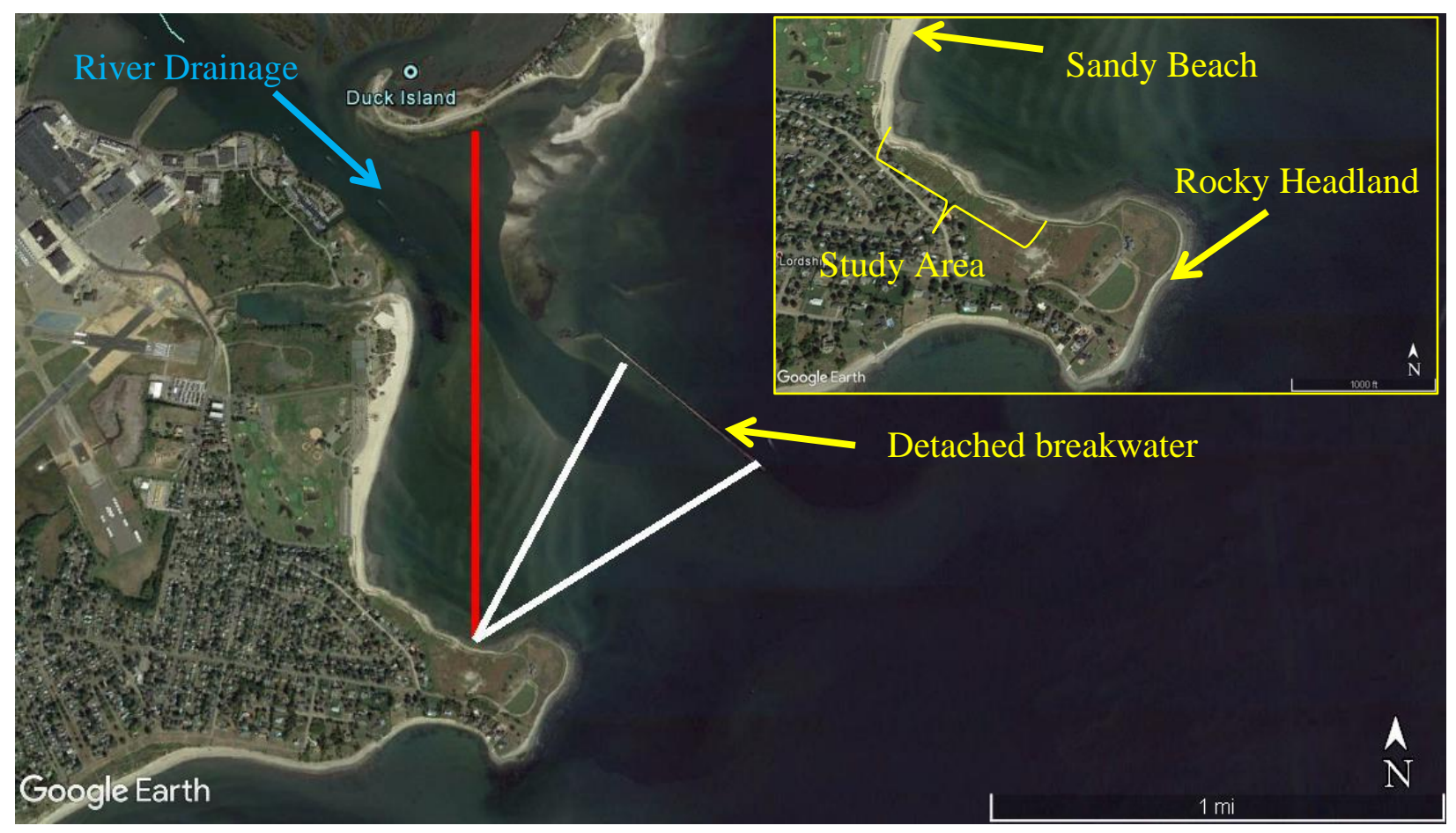

Figure 9: Short beach situation in the coats of Stratford in Connecticut, the coastline is surrounded by headland in south and Housatonic River in North. Fetch length is strongly restricted in the area and the maximum fetch length is about $2 \mathrm{~km}$ from North (red Line). Tidal and river currents are the primary source of energy in the coastline.

The Google Earth satellite images were used to compare coastline variation between 04/11/1991 and 09/22/2015 (14 years) at the southern part of Short beach. According to Figure 10, erosion happened in the coastline, excluding a small portion of the northern part. This coastline has a unique condition for establishing a coastal protection system by marsh due to the availability of sediment source from the river and the coastline's low wave energy.

This coastline used to be an ecological coastline for crabs to lay their eggs. However, because of erosion and washed out sands, the number of horseshoe crabs has been dropped significantly (Beekey et al. 2015). Therefore, a survival plan has been implemented from early 2015, including setting up a group of reef balls and salt marsh to trap finer and organic sediment and provide a suitable coastline for crabs for laying the eggs, Figure 11. There is no data on how the system has been designed, but the system is working well! 


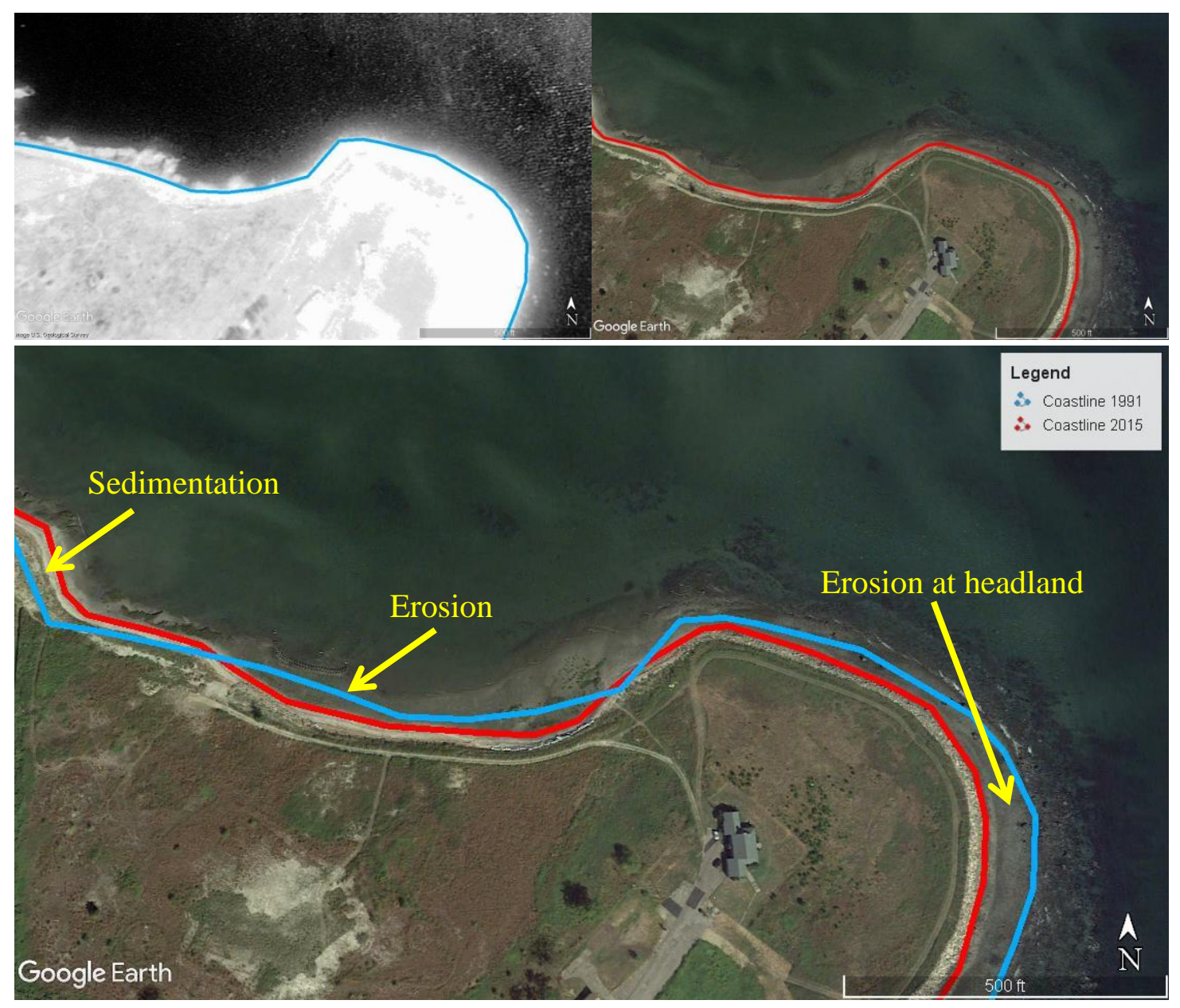

Figure 10: Comparison of coastal variations between 04/11/1991 and 09/22/2015 (14 years) in Short beach, top left: 1991 image, top right: 2015 image, bottom: the Comparison of two coastlines. About $2700 \mathrm{~m}^{2}\left(29000 \mathrm{ft}^{2}\right)$ of the coastline and $5000 \mathrm{~m}^{2}\left(54000 \mathrm{ft}^{2}\right)$ of the headland has been eroded in 14 years. However, there is small sedimentation at the northern part.

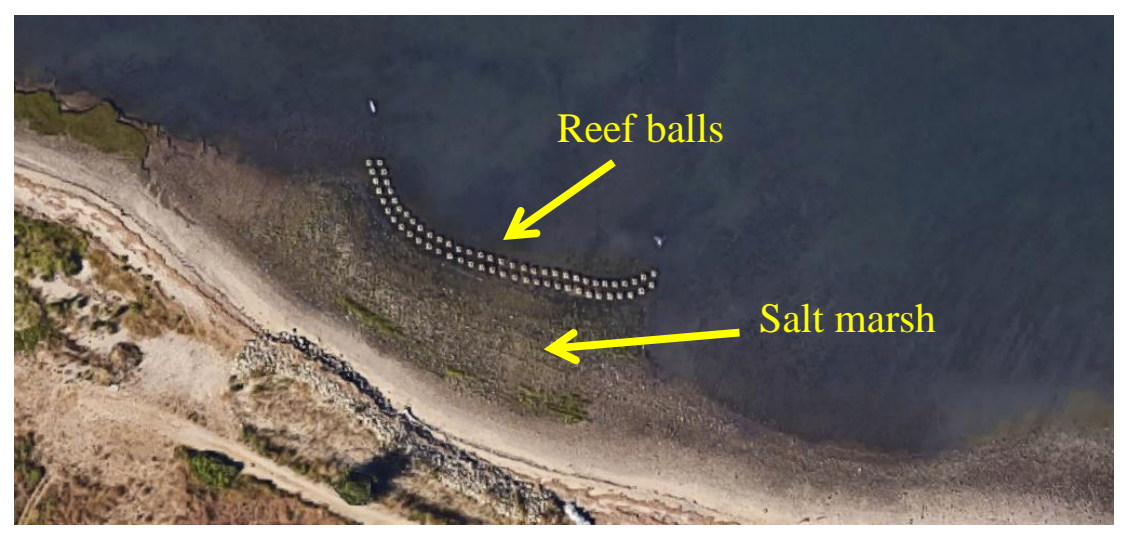

Figure 11: Ecological- based coastal protection system in Short Beach. Since setting up the protection system, sediment erosion has stopped and the system successfully trapped sand and finer sediment 


\section{Conclusion}

Saltmarsh can be used for coastal protection. They can attenuate waves, stabilize soil and depose sediments. The power of marshes for attenuating waves generally increases with the length. Marsh edge dissipation rate for high-frequency waves (sea-waves) is more than low-frequency waves (swell waves). In addition, marsh root has a stabilizing effect and it binds soil bulk and protects it from erosion. It's noticeable that salt marshes are effective in low wave energy and a large wave can eradicate salt marshes.

Furthermore, marsh can be used for attenuating storm surge as well. However, despite erosion protection, a large wetland is required for protecting upland from storm surge. Also, salt marsh can adapt to relative SLR by sediment accretion and upland migration. Having enough sediment supply and a gentle upland slope can guarantee salt marsh adaptation to SLR. Therefore, to develop a sustainable and resilience protection system by salt marsh, it's essential to provide a calm wave condition on the site, which can be done by constructing reef balls and submerged breakwater seaside of the constructed marsh. Also, the sediment supply must be enough to guarantee a structured marsh adaptation to SLR. Preferentially, there should be a gentle upland slope, especially for low sediment supply conditions. Finally, there are other factors, the effect of which are not well-understood such as vegetation density, type, and stiffness as well as ecological factors, such as nutrient supply and vegetation disease. These factors also should be taken into account in the design.

Connecticut coastlines have limited wave energy, which is a positive factor for the growing marsh due to short fetch length. Available historical data indicates that currently total acreage of Connecticut salt marshes is constant or increasing. Also, average accretion rates are close to current SLR and it seems that Connecticut marshes could keep pace with current SLR.

A feasibility study on two coastlines, Chittenden Park in Guilford and Short Beach in Stratford, was done. Generally, wave energy is limited in Connecticut coastlines, but the assessment of fetch length and dominant wind directions showed that in Short beach, wave energy is more restricted than Chittenden Park coastline. The lack of data about river sediment supply as well as the nonuniform form of Connecticut coastline has made it complicated to determine sediment availability in the specific coastline. However, it seems that sediment availability in Short Beach is more than in the Chittenden Park coastline, while it needs more measurements and studies. A comparison of satellite images showed that erosion in Chittenden Park is much more intense than the Short beach coastline. In addition, Hurricane Sandy was the main driver of intensive erosion in the Chittenden Park coastline. 


\section{References:}

1. Akan, A. O. (2006). Amsterdam; Boston: Oxford [England]; Burlington, Mass.: Elsevier; ButterworthHeinemann.

2. Basso G., O'Brien K., Albino Hegeman M. and O'Neill V., (2015). Status and trends of wetlands in the Long Island Sound Area: 130 year assessment. U.S. Department of the Interior, Fish and Wildlife Service. (36 p.)

3. Beekey M.A., Mattei J. H., (2015), The Mismanagement of Limulus polyphemus in Long Island Sound, U.S.A.: What Are the Characteristics of a Population in Decline?, Changing Global Perspectives on Horseshoe Crab Biology, Conservation and Management, pp 433-461, doi: 10.1007/978-3-319-19542-1_25

4. Browne, M.A., Chapman, M.G., (2014). Mitigating against the loss of species by adding artificial intertidal pools to existing seawalls. Mar. Ecol. Prog. Ser. 497, 119-129.

5. Buckley S., Al--Haj A., Fulweiler R. (2016) Sentinels of Change - Are Salt Marshes in LIS Keeping Pace with Sea Level Rise?, Boston University, U.S. Environmental Protection Agency.

6. Clough J., Polaczyk A., Propato M. (2016) Advancing Existing Assessment of Connecticut Marshes' Response to SLR, U.S. Fish and Wildlife Service, Northeast Regional Oceans Council, Connecticut, Warren Pinnacle Counmsulting,

7. Gedan, K.B., Kirwan, M.L., Wolanski, E. et al., (2011), The present and future role of coastal wetland vegetation in protecting shorelines: answering recent, challenges to the paradigm Climatic Change, 106: 7. doi:10.1007/s10584-010-0003-7.

8. Gittman, R.K., Popowich, A.M., Bruno, J.F., Peterson, C.H., (2014). Marshes with and without sills protect estuarine shorelines from erosion better than bulkheads during a Category 1 hurricane. Ocean Coast. Manage. $102,94-102$

9. Hill, T.D., and S. C. Anisfeld (2015), Coastal wetland response to sea level rise in Connecticut and New York, Estuarine Coastal Shelf Sci., 163, 185-193.

10. Ilia, A., \& O'Donnell, J. (2018). An Assessment of Two Models of Wave Propagation in an Estuary Protected by Breakwaters. Journal of Marine Science and Engineering, 6(4), 145. MDPI AG. Retrieved from http://dx.doi.org/10.3390/jmse6040145

11. Ilia, A., McCardell, G., \& O'Donnell, J. (2019). Turbulence Enhancement by Surface Gravity Waves in a Large Estuary: Observation and Modeling. AGUFM, 2019, GC44A-06.

12. Ilia, A., Donnell, J., \& Mattei J. (2017). The Potential Role of Salt Marsh on Coastal Protection and Resilience. 2017 AGU Fall Meeting.

13. Jadhav R.S., Chen Q., Smith J.M. (2013) Spectral distribution of wave energy dissipation by salt marsh vegetation, Coastal Engineering, Vol 77, Pages 99-107.

14. Ketabdari, M. J., Ilia, A., \& Karimi, M. (2015, March). A model study of wind-induced sea level fluctuations in the Persian Gulf and the Gulf of Oman. In AIP Conference Proceedings (Vol. 1648, No. 1, p. 770010). AIP Publishing LLC.

15. Kirwan, M. L., G. R. Guntenspergen, A. D'Alpaos, J. T. Morris, S. M. Mudd, and S. Temmerman (2010), Limits on the adaptability of coastal marshes to rising sea level, Geophys. Res. Lett., 37, L23401, doi:10.1029/2010GL045489. 
16. Kirwan, M. L., D. C. Walters, W. G. Reay, and J. A. Carr (2016), Sea level driven marsh expansion in a coupled model of marsh erosion and migration, Geophys. Res. Lett., 43, 4366-4373, doi:10.1002/2016GL068507.

17. Kirwan, M. L., and J. P. Megonigal (2013), Tidal wetland stability in the face of human impacts and sea-level rise, Nature, 504, 53-60.

18. Kirwan, M. L., Temmerman, S., Guntenspergen G R., Fagherazzi S., (2016), Overestimation of marsh vulnerability to sea level rise. Nature Climate Change, 6, 253-260, doi:10.1038/nclimate2909

19. Moller, I., Kudella, M., Rupprecht, F., Spencer, T., Paul, M., van Wesenbeeck, B., Wolters, k., Jensen, G., Bouma, K., Miranda- Lange, T.J., Schimmels, M.S., (2014). Wave attenuation over coastal salt marshes under storm surge conditions. Nat. Geosci. 7, 727-731

20. http://www.ct.gov/deep/cwp/view.asp?a=2705\&q=475764\&deepNav_GID=2022

21. O'Donnell J.E.D. (2016) Living Shorelines: A Review of Literature Relevant to New England Coasts, Journal of Coastal Research: Volume 33, Issue 2: pp. 435 - 451.

22. O'Donnell J. (2017), Sea Level Rise and Coastal Flood Risk in Connecticut, Department of Marine Sciences \& Connecticut Institute for Resilience and Climate Adaptation, The University of Connecticut.

23. Shepard CC, Crain CM, Beck MW (2011) The Protective Role of Coastal Marshes: A Systematic Review and Meta-analysis. PLoS ONE 6(11): e27374. doi:10.1371/journal.pone.0027374.

24. Sutton-Grier A.E., Wowk K., Bamford H., (2015). Future of our coasts: The potential for natural and hybrid infrastructure to enhance the resilience of our coastal communities, economies and ecosystems, Environmental Science \& Policy, 51, P 137-148

25. Temmerman, S., P. Meire, T. J. Bouma, P. M. J. Herman, T. Ysebaert, and H. J. De Vriend (2013), Ecosystembased coastal defence in the face of global change, Nature, 504, 79-83.

26. Tiner, R.W., I.J. Huber, T. Nuerminger, and E. Marshall. (2006). Salt Marsh Trends in Selected Estuaries of Southwestern Connecticut. U.S. Fish and Wildlife Service, National Wetlands Inventory Program, Northeast Region, Hadley, MA. Prepared for the Long Island Studies Program, Connecticut Department of Environmental Protection, Hartford, CT. NWI Cooperative Report. 20 pp.

27. www.un.org/esa/sustdev/natlinfo/indicators/...sheets/...coasts/pop_coastal_areas.pdf, UN, Division for Sustainable Development 